BERNADETA WILK

\title{
AUTONOMICZNY KRAKÓW SKARBNICĄ NARODOWYCH PAMIĄTEK
}

W historii Polski i w rozwoju polskiej kultury Kraków odegrał ogromną rolę. Wszedłszy w skład państwa pierwszych Piastów stał się jednym z głównych jego grodów, zyskując wkrótce rangę stolicy. W okresie rozbicia dzielnicowego był miejscem jednoczącym podzielone ziemie Polski, a panowanie nad nim stanowiło o uznawanym powszechnie prymacie w kraju. Jako stolica zjednoczonego królestwa, a potem państwa polsko-litewskiego, należal do głównych stolic europejskich, a w czasach upadku, w XVII i XVIII wieku, nadal pozostawał miejscem koronacji i wiecznego spoczynku władców Polski. Wraz z utratą niepodległości zaczął odgrywać szczególną rolę, miast-symbolu, miasta-świątyni i skarbca, skupiającego uczucia podzielonego narodu.

Nadanie Galicji autonomii i przywrócenie samorządu miejskiego w Krakowie w 1866 roku stało się impulsem do rozwoju Krakowa i przywrócenia jego dawnej świetności. Na mocy Tymczasowego statutu gminnego dla stolecznego, królewskiego miasta Krakowa przywrócono tradycyjną nazwe „stołecznego, królewskiego miasta Krakowa", choragiew i herb oraz język polski jako urzędowy'. Było to tym ważniejsze, że $w$ dwóch pozostałych zaborach zmiany zaszły w zupełnie odwrotnym kierunku. W Królestwie Polskim, po stlumieniu Powstania styczniowego (1864 r.), rozpoczął się rusyfikacyjno-represyjny system rządów Hurki i Apuchtina, a Polacy w zaborze pruskim zostali poddani bezwzględnej germanizacji żelaznego kanclerza pruskiego Bismarcka, połączonej ze zwalczaniem kultury polskiej i ograniczaniem roli Kościoła polskiego w ramach Kulturkampfu. W tym samym czasie Kraków cieszył się dużymi swobodami, dzięki którym tu właśnie mogło pomyślnie rozwijać się polskie życie narodowe we wszystkich jego przejawach.

Dzięki uzyskanym swobodom, jakie dawała autonomia, po okresie głębokiej stagnacji gospodarczej i martwoty w wielu dziedzinach życia społecznego, nastapiło ożywienie życia we wszystkich jego przejawach. Wybrana 1 sierpnia 1866 roku nowa Rada Miejska realizowała ambitny program rozwoju Krakowa, nakreślony przez pierwszego prezydenta miasta, Józefa Dietla. Trafnie ocenił on możliwości rozwojowe miasta, co wyraził już w swoim inauguracyjnym przemówie-

' J. B i en i a r zów n a. J. M. M ałe ck i, Dzieje Krakowa, t. 3. Kraków w latach 1796-1918, Kraków 1979, s. 204-207, 225-227; A. C h m i e 1, Ustrój miasta Krakowa w XIX wieku, [w:] Kraków w XIX wieku, t. 1, Kraków 1932, s. 112. 
niu, rozpoczynającym pierwsze posiedzenie Rady Miejskiej 31 października 1866 roku mówiąc: „Trzeba, żeby ten Kraków, który nie może świetnić potęgą zasobów materialnych, świetniał potęgą zasobów duchowych"². Szansę rozwoju nowoczesnego Krakowa widział Dietl w czynnikach pozamaterialnych, a więc w nauce, kulturze i sztuce.

W okresie autonomii galicyjskiej (1860-1914) Kraków stanowił centrum polskiego życia kulturalnego, naukowego, religijnego i politycznego. O tej szczególnej roli Krakowa w tym czasie zadecydowała nie tylko sama autonomia, ale i symbolika tego miasta - dawnej stolicy państwa polskiego. Tu właśnie, dzięki sprzyjającym okolicznościom, nastapił w drugiej połowie XIX i na początku XX wieku bujny rozkwit kultury polskiej ${ }^{3}$. Kraków, miasto koronacyjne i nekropolia królewska, polski Rzym i skarbnica największych narodowych pamiatek, stał się centrum polskości, zyskując w XIX wieku miano „duchowej stolicy Polski”,

Tragedia rozbiorów spowodowała $\mathrm{w}$ społeczeństwie polskim wzrost nastrojów patriotycznych i zwrot ku wartościom rodzimej tradycji. Kraków, jako „sza-

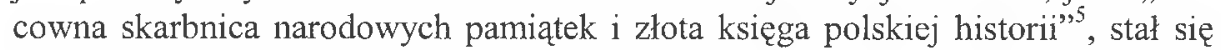
w naturalny sposób miastem pamięci Polaków, przechowującym ślady historycznej wielkości Polski. Oddziaływało na to skupienie pamiątek narodowych i wspaniałych pomników przeszłości. Kraków posiadał atut w postaci duchowego i materialnego dziedzictwa przeszłości, nagromadzonego przez stulecia, a już pierwsza połowa XIX wieku ugruntowała romantyczny mit Krakowa jako świętego miejsca Polaków, będącego źródłem pokrzepienia i nadziei. Uroczyste pogrzeby bohaterów narodowych w okresie Rzeczypospolitej Krakowskiej potwierdziły pehniona przez Wawel funkcję narodowego Panteonu, a sypanie kopca Kościuszki w 1820 roku, będącego symbolem dążeń niepodległościowych, umocniło znaczenie Krakowa jako ,polskiej Mekki”. Będąc stolicą nie istniejącego państwa, pojmowany był Kraków nie tylko jako symbol przeszłości historycznej i księga dziejowa narodu polskiego, ale także jako miasto - protoplasta, polski Rzym, a nawet ,polska Troja"

Dowodem szczególnej roli Krakowa u progu autonomii galicyjskiej stało się dzieło Józefa Kremera, wydane w 1870 roku, w którym czytamy: „Tak jest, odwieczny, ukochany Kraków nasz jest wróżbita, a prorokiem Polski, jest wszechziem rodzinnych ogniskiem a sercem, jest narodowości polskiej ożywczym sokiem. Gdyby w Krakowie już zamarly tętna ojczyste, gdyby z niego uleciało życie, gdyby go już opuścił duch, wtedy zaprawdę cała przeszłość narodu byłaby już

${ }^{2}$ Mowa dr Józefa Dietla, prezydenta miasta Krakowa, zagajajacca pierwsze posiedzenie

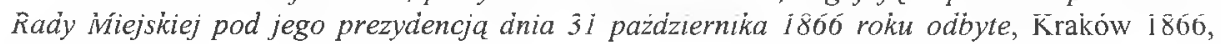
s. 10 .

${ }^{3}$ J. O s t row s k i, Kraków, Kraków 1989, s. 5-6.

${ }^{4}$ F. Z i e j k a, ,Tu wszystko jest Polskq...”. (O roli Krakowa w zyciu duchowym Polaków w wieku XIX), ,Rocznik Krakowski” 62:1996, s. 42-50; K. G r odz i s k a-O ż óg, Ze studiów nad rola Krakowa $w$ epoce porozbiorowej, „Rocznik Biblioteki Polskiej Akademii Nauk w Krakowie" 31:1986, s. 151.

${ }^{5}$ J. D u ż y k, „Polskie Ateny", [w:] Kraków stary i nowy. Dzieje kultury, red. J. Bieniarzówna, Kraków 1968, s. 343.

${ }^{6}$ J. B i e n i a rzó wn a, J. M. M ałe c ki, dz. cyt., s. 55-59.

${ }^{7}$ J. P u r c h l a, Matecznik Polski. Pozaekonomiczne czynniki rozwoju Krakowa w okresie autonomii galicyjskiej, Kraków 1992, s. 36. 
mrzonka, istną bajką! (...) Cała atoli przeszłość naszego narodu zostawiła darem w grodzie naszym upominki tak drogie sercu naszemu, jak są drogie dla dzieci upominki stawiające im przed oczy matkę zmarłą i strzegącą dzieci, by nie odstapiły od drogi powinności. Te zabytki, te miejsca wspomnień są jakby dotykalnymi świadkami i napominaja, byśmy tej przeszłości nie wypuścili z pamięci i ze serca. Wiele by nam czasu potrzeba, gdybyśmy mieli wyliczyć wszystkie te zabytki wspomnienia z dziejów narodu naszego. Możemy atoli przytoczyć, iż Kraków nie jest miastem, jak inne miasta. Kraków jest jakby jestestwem żywym, jakby duchem nieśmiertelnym, w nim kamienie mówią, a domy prawią legendy z dawnych czasów o świetności ojczyzny. (...) Kraków tajemniczą siłą swojej aureoli, a potęgą magiczną działa i przyciaga ku sobie. Nasi ziomkowie z nad Warty i Niemnu, znad Baltyku i progów Dnieprowych, jak islamita do Mekki, rzewnie tęsknią do Krakowa i pragną choć raz w życiu odetchnać pod tym jego klasycznym polskim niebem. Kraków nasz jest tak wysokiego dla wszystkich Polaków znaczenia, iż już śmiało orzec można, iż stopniem jego miłości ojczyzny, przywiązanie i życzliwość każdego z Polaków dla Krakowa jest zarazem miara jego polskości, jego uczuć ojczystych"8.

Ta symboliczna rola Krakowa, tak mocno i wieloznacznie pojmowana, nabrała nowego znaczenia w czasach autonomii galicyjskiej. Nowa sytuacja polityczna wytworzona w zaborze austriackim w latach sześćdziesiatych XIX stulecia stała się dla Krakowa szansą. Władysław Koziebrodzki w 1866 roku tak pisał: „Galicja w obecnej chwili ze wszystkich dzielnic Polski, znajduje się na najkorzystniejszym, najważniejszym i najwpływowszym stanowisku. Wyjątkowe to stanowisko nie tylko ogranicza się do jej wewnętrznych stosunków, lecz przeważnie dotyka i losów całej Polski, odpowiedzialność więc Galicji rośnie z ważnością zadania, trudnościami położenia. (...) Na Galicję w obecnej chwili patrzy cała Polska, patrzy mordowana i krwią zlana Litwa, patrzą zgnębione prowincje zabrane, patrzy zniszczone Królestwo, germanizowane gwałtem poznańskie. Galicja w obecnym położeniu chwilowo staje się sercem i ramieniem całej Polski. Wielkie zadanie, powtarzamy, i wielka odpowiedzialność. Na każdym kroku, przed każdym czynem Galicja nie tylko rachować się powinna $z$ samą sobą, lecz rachować z Polską całą, która na nią patrzy i czeka"".

Wyjątkowe położenie Krakowa, w porównaniu z ogarniętymi represjami i żałobą ziemiami polskimi zaboru rosyjskiego i gnębionymi germanizacją Polakami zaboru pruskiego, sprawiło, że ta dawna stolica Polski zaczęła spełniać funkcję ponadzaborowa, zdobywając jedno $z$ pierwszych miejsc $w$ dziejach narodu polskiego, będącego od 1795 roku pod zaborami. W stosunku do pozostałych ziem Kraków pełnił rolę centrum polskiego życia naukowego, kulturalnego, religijnego i politycznego, stając się miejscem integrujacym wszystkich Polaków ${ }^{10}$. Tutaj $z$ dużą swobodą rozwijało się życie narodowe i można było krzewić narodowego ducha Polaków i umacniać patriotyzm. Zdawano sobie bowiem sprawę, że jest to

${ }^{8}$ J. K r e me r, Kraków wobec Polski i Sukiennice jego oraz słowo o Bramie Florianskiej, Kraków 1870, s. 4, 13, 17-18.

${ }^{9}$ [Władysław Koziebrodzki], Galicja i Austria, Bendlikon 1866, s. 5.

${ }^{10}$ J. P u r c h 1 a, Kraków-prowincja, czy metropolia, Kraków 1996, s. 14. 
miasto idei, pamiątek historycznych i żywych tradycji, z których pokolenia moga czerpać „żywą wodę"11.

Specyficzna atmosfera Krakowa sprawiała, że miasto w tym czasie było celem licznych peregrynacji Polaków ze wszystkich zaborów, którzy stając w jego murach przeżywali fascynację przeszłością oraz uczyli się tutaj historii, wierząc w zmartwychwstanie ojczyzny. $Z$ tego powodu mówiono o Krakowie, ze jest „matecznikiem Polski"12. Do Krakowa przybywały, na stałe lub krótki pobyt, liczne rodziny z Królestwa i z Kresów, a także z zaboru pruskiego, a nawet emigra$\mathrm{cji}^{13}$. Pobyt w Krakowie był dla Polaków z innych ziem spotkaniem z Polską i polskościa. Wynikało to nie tylko ze specyficznej atmosfery i wolności, której tak brakowało w zaborze rosyjskim, ale i z różnicy sytuacji społeczno-gospodarczej Krakowa i Warszawy. Przybywający do Krakowa Polacy ,pławili się w polskiej wolności, kupowali broszki i szpilki z orzełkiem, pielgrzymowali na Wawel i Skałkę, oglądali z nabożeństwem obrazy Matejki w Muzeum Narodowym w Sukiennicach, (...) gapili się pełni zachwytu na Mariacką wieżę, pragnac dojrzeć strażnika otrębującego hejnał"14.

W ten sposób Polacy z zaboru rosyjskiego i pruskiego mogli bez trudności realizować w Krakowie swoje plany ,nasycania się polskością"15. Wycieczki pielgrzymki do Krakowa stały się głównym narzędziem w edukacji narodowej i wychowaniu patriotycznym mieszkańców Śląska, Poznańskiego, a także Galicji Wschodniej, dając pełniejsze poczucie przynależności narodowej oraz dumy z przeszłości ojczystej. Powołane w 1891 roku Towarzystwo Szkoły Ludowej przez wiele lat było organizatorem owych pielgrzymek do Krakowa, dla Polaków pragnących poznać zabytki i nauczyć się narodowej historii ${ }^{16}$. Takie urządzanie wycieczek (przy wykorzystaniu tradycji wiejskich) do pamiątek polskich, na wzór pielgrzymek, nazwano "patnictwem narodowym"17.

Przed pierwszą wojną światową organizacja wycieczek do Krakowa była bardzo dobrze zorganizowana. Do programu należało zwiedzanie kościołów krakowskich, grobów królewskich na Wawelu, Rynku, Kopca Kościuszki i Sukiennic. Liczne świadectwa odwiedzających to miasto dowodz̨, że ten „relikwiarz narodowych pamiątek"18 był dla przybyszów z różnych stron kraju i emigracji symbolem polskości oraz źródłem pokrzepienia i dumy narodowej ${ }^{19}$. ,Skarbnica wszystkich świętości dziejowych, Mekka i Medyna Bolesławowego dziela, ja-

${ }^{11}$ M. Roże k, Rola Krakowa w świadomósci narodowej, „Życie Szkoły Wyższej” 32:1984 nr 1, s. 54 .

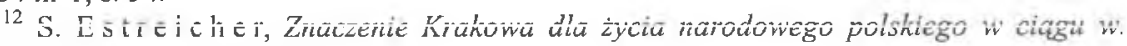
$X I X$, [w:] Kraków w XIX wieku..., s. 17;

${ }_{13}$ J. P u r c h l a, Matecznik Polski..., s. 51-55; idem, Autonomia galicyjska, a rozwój Krakowa na przetomie XIX i XX wieku, „Znak” 36:1984 nr 350, s. 63-67.

${ }_{14}^{14}$ M. T u r s k i, Czasy gimnazjalne, [w:] Kopiec wspomnień, Kraków 1959, s. 68.

${ }^{15}$ R. K a n tor, Kalejdoskop krakowski. Gawędy o Krakowie, krakowianach i ich zwyczajach, Toruń 1996, s. 22.

${ }^{16} \mathrm{Ibidem}, \mathrm{s} .25$; J. B i e n i a r z ó w na, J. M. M a ł e c k i, dz. cyt., s. 262-263.

${ }^{17}$ K. B o r e low s k i, Patnictwo narodowe. Przewodnik oświatowy, Kraków 1912, s. 3.

${ }^{18}$ F. Z i e j k a, dz. cyt., s. $35-42$.

${ }^{19}$ J. B i en i ar zów n a, J. M. M ałe ck i, op. cit., s. 259-264; F. Ziejka, op. cit., s. 40$-42,49-50$; R. K a n to r, dz. cyt., s. 21-27. 
śniała łuną olbrzymich wypadków dziejowych, świeciła potęgą nie własna, ale własnych wspomnieńn ${ }^{, 20}$.

Do tej dawnej stolicy Polski spieszyły rzesze „pątników narodowych”, którzy w zetknięciu z niezliczonymi pamiątkami wyobrażającymi ojczystą przeszłość odnajdowali swoją tożsamość. Kraków przełomu XIX i XX wieku był rzeczywistą księga narodowej historii, która wszystkim Polakom otwierała droge do Polski, zarówno robotnikom ze Śląska, dzieciom z Wielkopolski, jak i chłopom z Gali$\mathrm{cji}^{21}$. Takimi miejscami, w których szczególnie zdawano sobie sprawę z ,milczącej mowy kamieni" 22 , były Wawel i Skałka.

Wawel i katedra były od wieków chlubą i dumą Polski. To wyniosłe wzgórze, królujące nad Krakowem, symbolizowało odwieczną przeszłość i wspaniałe tradycje. Przemawiało do narodu, wzbudzając w duszy polskiej wiele skojarzeń i wzruszeń. Wyłaniające się z murów katedry i zamku wielkie postacie historyczne mówiły o chlubnej przeszłości, wyrażającej tożsamość narođową.

Katedra wawelska, kamienna księga dziejów ojczystych, pełniła kiedyś funkcję świątyni dworskiej przeznaczonej dla króla i jego rodziny. Na Wawelu koronowano królów i składano ich doczesne szczątki. Wyznaczały one historyczną ciagłość polskiej państwowości, stając się z upływem czasu symbolem trwałości narodowej i znakiem przeszłości. Ich rola została w pełni podjęta po upadku państwa polskiego w 1795 roku. W okresie niewoli narodowej groby monarsze na Wawelu, uświadamiając potęgę Rzeczypospolitej Obojga Narodów, zaczęły mieć znaczenie patriotyczne i wychowawcze. Jak ewangeliczne lapides vivi (żywe kamienie) uczyły Polaków dziejów ojczystych. Nekropolia wawelska przestała być już tylko cmentarzem królewskim, przekształcając się na początku XIX stulecia w symbol pobudzający do czynu.

Kult i pietyzm narodowy, jakim społeczeństwo polskie obdarzało groby królewskie, sprawily, że kiedy u schyłku XVIII wieku nie było już monarchów, postanowił naród składać w tym narodowym sanktuarium dziejowym, w podziemiach katedry na Wawelu, doczesne szczątki bohaterów narodowych i Królów $D u c h a^{23}$. Po kongresie wiedeńskim (1815 r.) zaczęto grzebać na Wawelu szczątki najbardziej zasłużonych dla ojczyzny, kontynuując w ten sposób historyczną tradycję. W katedrze wawelskiej, podobnie jak w angielskim opactwie Westminsterskim obok królów grzebano także bohaterów narodowych, wodzów, poetów, polityków i szczególnie zasłużonych dla ojczyzny.

W 1817 i 1818 roku mury wawelskie przyjęły szczątki dwóch wielkich Polaków. Tym razem nie królów, ale bohaterów narodowych. W 1817 roku (22-23 VII) odbyły się w Krakowie uroczystości pogrzebowe księcia Józefa Poniatowskiego, a rok później, 22-23 VI, złożono w krypcie św. Leonarda trumnę ze zwłokami Naczelnika Tadeusza Kościuszki ${ }^{24}$. Jako bohatera narodowego grzebano

${ }^{20}$ [Walerian Kalinka], Historia pożaru miasta Krakowa, Kraków 1850, s. 3.

${ }^{21}$ K. B or e low s k i, dz. cyt., s. I-2; B. C h r z a n ow s k i, Dziesięć lat tajnych wycieczek mlodzieży z zaboru pruskiego do Krakowa (1905-1914), „Niepodległość" 4:1931, s. 1.

${ }^{22}$ M. R o ż e k, Wawelska nekropolia, Kraków 1984, s. 22.

${ }^{23}$ M. R o ż e k, A. B u j a k, Nekropolie królów i ksiqżat polskich, Warszawa 1988, s. 37.

${ }^{24} \mathrm{~J}$. B u s z k o, Uroczystości patriotyczne na Wawelu w latach Rzeczypospolitej Krakowskiej $i w$ dobie autonomii galicyjskiej, "Annales Universitatis Mariae Curie-Skłodowska" sectio F:Historia, vol. 51:1996, s. 32-35; S. W in daki e w i c z, Dzieje Wawelu, Kraków 1925, s. 207-210. 
powtómie króla Kazimierza Wielkiego 8 lipca 1869 roku $^{25}$, a w 1890 roku pogrzebano na Wawelu prochy Adama Mickiewicza zmarłego w 1855 roku w Stambule.

W drugiej połowie XIX wieku Wawel i katedra królewska zaczęły pełnić rolę pierwszego w Polsce monumentu o funkcji nie tylko liturgicznej, ale przede wszystkim mauzoleum narodowego - pomnika historii, symbolu dumy i wielkości jednoczącego wszystkich bez wyjątku Polaków ${ }^{26}$. Wawel urastał do rangi polskiego Akropolis, relikwii narodowych dziejów, księgi historii Polski, z której kształciły się pokolenia zrodzone w niewoli ${ }^{27}$. Z prastarej katedry, która przed wiekami przyjmowała prochy królów, a teraz wielkich mężów, zaczęto tworzyć narodowy Panteon. Jego potrzebę rozumiano szczególnie w XIX wieku, kiedy grób integrował Polaków, przypominając ojczystą historię. W latach siedemdziesiątych XIX wieku wprowadzono zwyczaj odprawiania Mszy św. Żałobnych za dusze polskich monarchów. Ceremonie te odbywały się w rocznicę zgonu władcy w krypcie św. Leonarda o godzinie $10^{0028}$.

Kraków, przechowując najcenniejsze relikwie dziejowe, pozwolił Polakom przetrwać czas zaborów i niewoli, a niepoślednia rola w tej mierze przypadła wawelskiej nekropolii, o której Stanisław Windakiewicz pisał, że ,tak wzruszających katakumb nie posiada żaden naród. W dawniejszych czasach, przed powstaniem dzisiejszej Polski, było to jedyne miejsce, w którym myślało się o innej Polsce, niż ta, którą się pozostawialo za sobą. $Z$ pod całunu grobowego przemawiała inna rzeczywistość, niż ta, którą było otoczone społeczeństwo. Była to osobna krakowska poezja grobów, pokrewna poezji wyczuwanej na drodze apijskiej w Rzymie i na drodze cmentarnej w Pompei, z tą przecież różnica, że tamta uczuć patriotycznych w nikim nie budziła, a ta owszem drzemiący patriotyzm rozniecała" 29 .

Drugim po Wawelu, trwałym zwornikiem dziejów ojczystych stała się u początków państwowości polskiej Skałka. Wedle tradycjı, Skałka to miejsce męczeńskiej śmierci biskupa krakowskiego Stanisława ze Szczepanowa. Ofiara krwawej zemsty króla Bolesława Śmiałego, bp Stanisław stał się postacią, która mocno wrosła w dzieje narodu. Pośmiertny kult biskupa, kanonizowanego w 1253 roku i ogłoszonego patronem Krakowa i Polski, spowodował, że przez długie lata na Skałkę pielgrzymowali przed koronacją królowie polscy, komie chyląc czoła na miejscu męczeńskiej śmierci Stanisława, a wielcy wodzowie przed ołtarzem tego świętego modlili się o błogosławieństwo przed wyprawą na wojnę. Oltarz św. Stanisława został uznany przez Polaków za Oltarz Ojczyzny - Ara Patriae ${ }^{30}$. Od 1434 roku (od koronacji Władysława Warneńczyka) wszyscy królowie polscy, z wyjątkiem Stanisława Leszczyńskiego i Stanisława Augusta Poniatowskiego, odbywali pieszą pielgrzymkę z Wawelu na Skałkę w przeddzień uroczystości koronacyjnych.

${ }^{25}$ J. Bu szk o, Uroczystości kazimierzowskie na Wawelu w roku 1869, Kraków 1970, passim.

${ }^{26}$ M. R o że k, Wawel i Skatka-panteony polskie, Wrocław 1995, s. 5-6, 10.

${ }^{27}$ Idem, Wawelska nekropolia..., s. 22-23.

${ }^{28}$ Idem, Wawel i Skalka..., s. 138-139.

${ }^{29} \mathrm{~S}$. Wi n d a k i e wi c z, dz. cyt., s. 217.

${ }^{30}$ M. Rożek, „Ara Patriae". Dzieje grobu św. Stanislawa w katedrze na Wawelu, „Analecta Cracoviensia” 11:1979, s. 452-460. 
Skałka wzbudzała wyobraźnię nie tylko historyków, ale także pisarzy, poetów i uczonych. Kult św. Stanisława, królewskie pielgrzymki na Skałkę oraz legenda o życiu i tragicznej śmierci biskupa bez przerwy funkcjonowały w świadomości narodowej wszystkich Polaków. Na Skalkę podązały ludowe pielgrzymki, a sadzawka i grób świętego były miejscami sakralnymi. W okresie niewoli narodowej Kraków i cała Galicja zjednoczyły się pod patronatem św. Stanisława. Składano dziękczynne hołdy i okazywano wdzięczność za duchowe orędownictwo męczennika. Kiedy ustały monarsze pielgrzymki, natychmiast rozwinęły się coroczne procesje z Wawelu na Skałkę z relikwiami św. Stanisława ${ }^{31}$.

Dziewiętnasty wiek do trwającej od ośmiu stuleci rzeczywistości dodał nowy element, kształtując ogólnopolskie wyobrażenia o Skalce. Po uzyskaniu przez Galicję autonomii, kiedy wzrosło znaczenie Krakowa jako ogólnopolskiego centrum życia narodowego i kulturalnego, Skałka przyjęła na siebie jeszcze jedną funkcję sanktuarium kultury narodowej. Odtąd Skałka stała się panteonem najwybitniejszych Polaków, zyskując miano Grobu Ojczyzny - Sepulchrum Patriae ${ }^{32}$. Tu grzebano tych, którzy swą pracą tworzyli kulturę ojczysta, a w chwilach zaborów pozwolili dzięki swym dziełom przetrwać narodowi. W 1880 roku w krypcie kościoła na Skałce otwarto Groby Zastużonych Polaków. Dnia 19 maja 1880 roku w krypcie zasłużonych złożono kości Jana Długosza. Wkrótce potem obok grobowca wielkiego historyka pojawiły się sarkofagi poetów i artystów: Lucjana Sięmieńskiego (1881 r.), Wincentego Pola (1881 r.), Józefa Ignacego Kraszewskiego (1887 r.), Teofila Lenartowicza (1893 r.), Adam Asnyka (1897 r.), Henryka Siemiradzkiego (1902 r.) i Stanisław Wyspiańskiego (1907 r.). W ten sposób Skałka zaczęła pełnić rolę drugiego po Wawelu miejsca wiecznego spoczynku zasłużonych dla ojczyzny Polaków. Podwójna funkcja Skałki - liturgiczna i narodowa sprawiła, że Skałka zaczęła pełnić ważną funkcję w historii Polski i Polaków.

Autonomiczny Kraków odgrywał doniosłą rolę w życiu religijnym i duchowym Polaków, będących w niewoli narodowej. Na przełomie wieków to miasto stało się najważniejszym ośrodkiem życia religijnego na całym obszarze dawnej Rzeczypospolitej i poza jej granicami. Bujny rozkwit religijności zadecydował

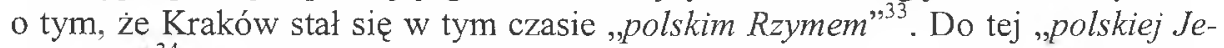
rozolimy" ${ }^{\text {,34 }}$ podążali pielgrzymi już w XV wieku, a nuch pątniczy przybrał na sile w drugiej połowie XIX wieku. To szczególne miejsce w życiu religijnym Polaków zawdzięczał Kraków relikwiom świętych i błogosławionych, znajdującym się w jego kościołach.

Kult polskich świętych i błogosławionych był ważnym dziedzictwem historycznym w kulturze polskiej, a jego tradycyjne formy uzyskały na przełomie stu-

${ }^{31}$ J. M o z ga, Historyczna rola sanktuarium św. Stanistawa w Krakowie na Skatce wczoraj i dziś, „Studia Claromontana” 17:1997, s. 16-17; M. T o b i a s z, Dziejowe znaczenie Skatki, ,Tygodnik Powszechny" 8:1952 nr 7, s. 8.

${ }^{32}$ M. R o ż e k, Wawel i Skatka..., s. 217; Idem, Skatka jako Panteon Narodowy, ,Peregrinus Cracoviensis" 14:2003, s. 122.

${ }^{33}$ B. P r u s, Kartki z podróży, t. 1, Warszawa 1950, s. 155; W. M. B a rte l, Czy Kraków na przetomie XIX i XX wieku byt "polskim Rzynem", [w:] Kraków na przetomie XIX i XX wieku. Materiaty sesji naukowej z okazji dni Krakowa w 1981 roku, red. I. M. Malecki, Kraków 1983 , s. 75. -35 .

${ }^{34}$ K. A n t on i ew i c z, Kazania, t. 3, Kraków 1906, s. 325; F. Z j e j k a, dz. cyt., s. 31- 
leci nowe znaczenie w życiu narodu polskiego ${ }^{35}$. Na czoło wysunął się w tym czasie kult św. Stanisława, biskupa i męczennika, który uzyskał zasięg ogólnonarodowy. Do ołtarza tego świętego, patrona Polski i Krakowa, ciagnęli przez całe stulecia pielgrzymi, a corocznie w dniu jego święta, 8 maja, urządzano uroczyste procesje $\mathrm{z}$ Wawelu na Skałkę z udziałem licznie przybyłego duchowieństwa i wiernych. Średniowiecza sięgał także w Krakowie kult św. Jacka Odrowąża, którego relikwie spoczywają w kościele Świętej Trójcy u dominikanów oraz kult św. Jana Kantego, profesora Uniwersytetu Jagiellońskiego, jednego z głównych patronów Polski. Przez cały wiek XIX św. Jan Kanty cieszył się u Polaków wielką czcią, a przybywający do Krakowa, pielgrzymi nawiedzali jego grób w kościele św. Anny. Od XV wieku trwał w Krakowie i nie tylko, kult królowej Jadwigi. Do znajdujaccego się w katedrze wawelskiej jej grobu napływały thumy pielgrzymów z całej Polski, aby oddać hołd tej władczyni, powszechnie uznawanej za świętą.

Obok świętych cieszących się kultem ogólnopolskim w Krakowie rozwijał się także lokalnie kult innych wybrańców bożych. Przez całe wieki trwał w kościele Św. Marka kult świątobliwego Michała Giedroycia. W kościele Św. Katarzyny u Augustianów kultem otoczone były relikwie błogosławionego Izajasza Bonera, a w położonym nieopodal kościele Bożego Ciała, błogosławionego Stanisława Kazimierczyka. W położonym u stóp Wawelu kościele Bernardynów, pielgrzymi modlili się przy grobie błogosławionego Szymona z Lipnicy, a świątobliwego Świętosława Milczącego czczono w kościele Mariackim.

Rangę Krakowa jako polskiej Jerozolimy wyznaczał przede wszystkim słynący cudami czarny krzyż świętej Królowej Jadwigi w katedrze na Wawelu i sanktuarium krzyża mogilskiego u cystersów w Mogile. Przez kilka stuleci podążali do tych miejsc w okresie oktawy Podwyższenia Krzyża świętego i w czasie Wielkiego Tygodnia pielgrzymi ze wszystkich stron kraju. Od niepamiętnych czasów wierni nawiedzali krakowskie świątynie, w których do dziś znajdują sıę cudowne obrazy Matki Bożej. Odwiedzali cudowny obraz Matki Bożej Różańcowej w kościele Świętej Trójcy u dominikanów oraz wielką czcią darzyli wizerunek Matki Bożej Bolesnej Smętnej Dobrodziejki w kościele Franciszkanów Konwentualnych. Wiernych przyciagaly także dwa cudowne obrazy w kościele Karmelitów „trzewiczkowych”: Matki Bożej „Piaskowej” i Matki Bożej Szkaplerznej. Od wieków spieszyli też do cudownego obrazu Matki Bożej Świętojańskiej „od wykupu niewolników”, znajdujący się w kościele Św. Jana Chrzciciela i Św. Jana Ewangelisty. Nie brak było wiernych proszących łask przed obrazem Matki Bożej Śnieżnej u sióstr dominikanek „na Gródku”. Przybywający do Krakowa w drugiej połowie XIX i w pierwszych latach XX wieku pielgrzymi modlili się także przed słynącym łaskami cudownym krucyfiksem w kościele Kapucynów, przed cudownym obrazem Matk1 Bożej Nieustającej Pomocy w kościele Św. Floriana oraz przed cudownym obrazem św. Józefa w kościele Bernardynek przy ul. Poselskiej ${ }^{36}$.

Od najdawniejszych czasów Kraków był miastem licznych zakonów męskich i żeńskich. W 1914 roku na terenie miasta znajdowało się 46 kościołów, miało siedziby 11 zakonów męskich i tyle samo żeńskich z około 530 zakonnikami i 820

${ }^{35}$ D. Olszewski, Polska kultura religijna na przetomie XIX $i$ XX wieku, Warszawa 1996 , s. 201.

${ }^{36}$ F. Z i e j k a, dz. cyt., s. 32-34. 
zakonnicami $^{37}$. Już na początku XII wieku osiedlili się cystersi, dominikanie (1222 r.) oraz franciszkanie (1237 r.). Oprócz wymienionych wyżej swoje siedziby mieli tu także paulini i bernardyni, kapucyni i redemptoryści, karmelici bosi i karmelici trzewiczkowi, reformaci, bonifratrzy, jezuici, misjonarze, kanonicy laterańscy, salezjanie, zmartwychwstańcy, pijarzy, salwatorianie, kameduli i augustianie. W 1888 roku malarz Albert Chmielowski (brat Albert) założył Zgromadzenie Braci Albertynów, a dwa lata później powołano żeńską gałąź zgromadzenia, sprawującą opiekę nad kobietami. Członkowie zgromadzenia nieśli pomoc ubogim i chorym, a od roku 1889 objęli opieką miejskie ogrzewalnie dające schronienie bezdomnym Krakowa.

Na przełomie XIX i XX wieku było w Krakowie kilkanaście zgromadzeń zakonnych żeńskich. Swoje domy klasztome miały tu: dominikanki, klaryski, urszulanki, karmelitanki bose, norbertanki, prezentki, bernardynki, sercanki, augustianki, wizytki, duchaczki i siostry miłosierdzia. Po upadku Powstania Styczniowego przybyło do Krakowa wiele zgromadzeń zakonnych wypędzonych z zaboru rosyjskiego i pruskiego. Kraków bowiem uniknął kasat klasztorów w okresie józefinizmu i represji, jakie cierpiały zakony po 1863 roku w zaborze rosyjskim i w czasie Kulturkampfu w zaborze pruskim. Obok licznych już istniejących pod Wawelem zgromadzeń zakonnych do Krakowa przybyły w 1865 roku wypędzone z Warszawy felicjanki ${ }^{38}$, a w 1876 roku wygnane z Poznania urszulanki. Z emigracji powrócili zmartwychwstańcy, jezuici i pijarzy.

Sława Krakowa jako miasta świętego sprawiła, że w drugiej polowie XIX wieku, kiedy władze carskie rozpoczęły prześladowanie unitów, właśnie tutaj skierowały się serca tych nowożytnych męczenników. Pod koniec XIX stulecia przybyli chłopi uniccy z Chełmszczyzny i Podlasia, gdzie odmawiano im prawa praktyk religijnych i zmuszano do przechodzenia na prawosławie. W kościele Św. Norberta przy ul. Wiślnej, gdzie była parafia unicka, oraz w kościele Św. Piotra i Pawła przy ul. Grodzkiej przybysze z Podlasia, zwani opornymi, przystępowali do sakramentów świętych, zawierali małżeństwa (śluby krakowskie) i chrzcili swoje dzieci ${ }^{39}$.

Obecność w Krakowie cudownych obrazów i krucyfiksów, relikwii świętych i błogosławionych, a także wielka liczba kościołów i klasztorów sprawiły, że podwawelski gród w czasach niewoli narodowej był, obok Jasnej Góry, najważniejszym ośrodkiem życia religijnego wszystkich Polaków.

Autonomiczny Kraków był widownią różnych zwyczajów i obrzędów właściwych tylko temu miastu, z których można było odczytać zamierzchłe czasy duchowej i społecznej kultury. Lud krakowski pielęgnował i podtrzymywał tradycję oraz stare obyczaje mieszczańskie i ludowe. Wyrażało się to przeważnie w obchodach związanych z różnymi świętami roku kościelnego. Do najbardziej znanych należało: chodzenie z szopka, Emaus, Rękawka, Wianki. Staropolski zwyczaj szopki rozwinął się w Krakowie w drugiej połowie XIX wieku. Ozdobne szopki,

${ }^{37}$ J. B i en iarzówna, J. M. M ał e ck i, dz. cyt., s. 251.

${ }^{38}$ A. P e tran i, Kasata klasztoru ss. Felicjanek w Warszawie w 1864 r. w świetle źródel rosyjskich, „Nasza Przeszłośc”" 35:1971, s. 161-162.

${ }^{39}$ F. Z i e j k a, dz. cyt., s. 34; W. M. B a rt e l, dz. cyt., s. 79-80, 82-83; B. P r z y byszew ski, Zarys dziejów diecezji krakowskiej (do roku 1994), Kraków 2000, s. 47-49, 59; J. B i en i arzów na, J. M. M ał e c k i, dz. cyt., s. 264. 
wzorowane na architekturze krakowskiej, obnoszono w okresie Bożego Narodzenia po domach, odgrywając przedstawienia jasełkowe. Teksty jasełek były w Krakowie bardzo populame, a wprowadzane do nich postacie ludowe (krakowiacy, górale) i historyczne (Tadeusz Kościuszko) wyposażano w akcenty patriotyczne. Odgrywana od wieków szopka krakowska przewyższała swoją pięknością i popularnością wszystkie jasełka w całej Polsce. Ze świętami Wielkanocy łączyły się dwa odpusty: jeden na Zwierzyńcu w Poniedziałek wielkanocny, zwany Emaus i drugi następnego dnia, na Krzemionkach, pod nazwą Rękawka. W dzień św. Stanisława, 8 maja, odbywał się na Skałce odpust połączony z uroczystą procesją z Wawelu na Skałkę. W czasie Zielonych Świąt organizowano majówki na Bielanach, będace ulubiona rozrywką krakowian i ludu wiejskiego. Od 1870 roku Karol Miarka zapoczątkował tradycję organizowania pielgrzymek z Górnego Śląska do Krakowa w okresie Zielonych Świąt ${ }^{40}$. W ostatnich dziesięcioleciach XIX wieku rozwinięto i upiększono obchód Lajkonika czyli Konika zwierzynieckiego, gromadzącego corocznie w oktawę Bożego Ciała tłumy na Rynku. Znane w całej Polsce zwyczaje sobótkowe w noc świętojańską (wigilię św. Jana) łączono w Krakowie z legendą o Wandzie i od lat siedemdziesiątych XIX wieku obchodzono coraz bardziej okazale. Iluminacje, sztuczne ognie, przepływajace galary ściągały nad Wisłę u podnóża Wawelu tłumy widzów, czyniąc „wianki” prawdziwą zabawą ludową ${ }^{41}$.

Z uroczystości kościelnych wybijała się zawsze w Krakowie na pierwsze miejsce procesja na Boże Ciało: katedralna, mariacka i dwie dominikańskie w oktawie Bożego Ciała i na święto Matki Bożej Różańcowej w pierwszą niedzielę października. Żadne z miast polskich nie mogło poszczycić się ani takim tłem jak Rynek krakowski, ani takimi malowniczymi strojami ludowymi. Procesje na Boże Ciało odbywały się we wszystkich kościołach parafialnych. Niesiono w nich najpiękniejsze choragwie i feretrony, a także pojawiały się oryginalne stroje cechowe i tradycyjne stroje mieszczek krakowskich. Wszystkim procesjom towarzyszyło bicie w kotły, a procesji katedralnej asystowało wojsko wraz z orkiestra. Na przełomie 1860/1861 roku obywatele w polskich strojach narodowych nieśli baldachim, co dodawało zewnętrznego blasku i nastroju tym uroczystościom. $\mathrm{Na}$ procesję różańcową licznie przybywały też pielgrzymki z okolic, a corocznie spieszyli do Krakowa Ślązacy na święto Matki Bożej Różańcowej i do grobu św. Jacka (ich rodaka). Lud wiejski chętnie przybywał na wrześniowy odpust w święto Narodzenia Matki Bożej u karmelitów „na Piasku”. W drugiej połowie XIX wieku wprowadzono do kościołów krakowskich nabożeństwa majowe, które od razu zyskały sobie wielką populamość. Rozpowszechnione było również śpiewanie wieczorami pieśni przeđ figurami Matki Bożej Łaskawej przed kapucynami i figurą św. Jana Nepomucena kolo karmelitów „na Piasku” oraz procesje w kościele Św. Anny w oktawę św. Jana Kantego, w której brali udział profesorowie Uniwersytetu Jagiellońskiego w togach i galowych mundurach. W czasie oktawy śpiewano wieczorem w mieszkaniu świętego w Collegium Maius ${ }^{42}$.

${ }^{40}$ Ibidem, s. 40.

${ }^{41}$ M. Estre ich e rów na, Życie towarzyskie i obyczajowe Krakowa w latach 18481863, Kraków 1968, s. 189-200; J. B i en i a rzów n a, J. M. M ał e ck i, dz. cyt., s. 329-330 ; S. E s tr e i c her, dz. cyt., s. 20.

${ }^{42}$ Ibidem, s. 204-207. 
Z chlubą podtrzymywało się w Krakowie zwyczaj noszenia kontuszy, czamar i siermięg przy okazji ceremonii liturgicznych, związanych z rokiem kościelnym. Przywrócono starodawne stroje (togi) dla rektora i profesorów Uniwersytetu Jagiellońskiego, wskrzeszono nabożeństwa akademickie do św. Jana Kantego w kolegiacie Sw. Anny, a w 1887 roku wprowadzono uroczysty obrzęd inauguracji roku akademickiego $\mathrm{z}$ pochodem $\mathrm{w}$ togach, który przypominał wszystkim mieszkańcom dawne czasy świetności tej krakowskiej wszechnicy ${ }^{43}$.

Dzieje Krakowa związane z ogólnopolską symboliką nabrały po rozbiorach szczególnej wymowy. Niezależnie bowiem od ważnych dla miasta zdobyczy cywilizacyjnych o wiele większe znaczenie miał rozkwit kulturalny Krakowa, co na dłuższy czas nadało miastu rangę duchowej stolicy Polski. Rola Krakowa jako symbolu i jego wielkiej roli dziejowej zarysowała się już w czasach Rzeczypospolitej Krakowskiej, a wyraźnie rozwinęła w latach autonomil galicyjskiej 1860--1914. W sferze symboliki patriotycznej, stanowiącej ważny czynnik krzewienia i umacniania świadomości narodowej, doniosłą rolę zaczęły odgrywać organizowane pod Wawelem uroczystości patriotyczno-religijne ${ }^{44}$. Dla krzewienia idei patriotycznych Kraków sięgnał do zasobów historii. Ustalił się pewnego rodzaju „archeologiczny patriotyzm", dowych, jubileuszy i celebrowaniu pogrzebów zasłużonych Polaków. Te krakowskie fety, w których treści religijne zespolone były ściśle z treściami patriotycznymi, przypominały burzliwe dzieje Polski, a odsłaniając najchlubniejsze karty w naszej historii pobudzały do czynu i walki o niepodległość. Były ważną dla narodu pozbawionego własnej państwowości manifestacją woli przetrwania w niesprzyjających okolicznościach oraz okazją do spotkania się Polaków ze wszystkich zaborów.

Kraków od drugiej połowy XIX stulecia do wybuchu pierwszej wojny światowej przeżywał drugi po czasach Rzeczypospolitej Krakowskiej okres swojej świetności. Większe niż w innych zaborach, chociaż wciąż ograniczone swobody polityczne przyczyniły się do tego, że Kraków stał się najważniejszym ośrodkiem życia społeczno-politycznego Galicji oraz centrum polskiego życia narodowego. Wielka przeszłość historyczna miasta, upamiętniona wieloma doniosłymi wydarzeniami dla państwa i narodu, tradycja oraz bogaty folklor podkrakowskiej wsi sprawiły, że Kraków przełomu XIX i XX stulecia zdobył pierwszoplanowe miejsce w życiu zgnębionego narodu, urastając niemal do rangi symbolu Polski.

Kraków w okresie autonomii galicyjskiej był „Polski sercem, a narodowości ogniskiem świętym, przedstawcą ojczystych dziejów" ${ }^{\text {"46 }}$ i siedliskiem polskiego ducha narodowego. $Z$ tego podwawelskiego grodu promieniowała na cały naród przeszłość Polski, a kultywowane tu stare tradycje i obyczaje podtrzymywały ducha narodowego Polaków w ciężkich chwilach niewoli, rozbudzając nadzieję

${ }^{43}$ S. Es stre i c her, dz. cyt., s. 20.

${ }^{44} \mathrm{O}$ obchodach narodowo-kościelnych $\mathrm{w}$ autonomicznym Krakowie napisałam obszerniej w mojej pracy magisterskiej pod kierunkiem ks. prof. dr. hab. Stanisława Piecha. Zob. B. W i $1 \mathrm{k}$, Uroczystości patriotyczno-religijne w Krakowie w okresie autonomii galicyjskiej 1860 1914, Kraków 2003. (Archiwum PAT, mps, H-279).

${ }^{45}$ J. Ostrows k i, dz. cyt., s. 91.

${ }^{46}$ J. K re me r, dz. cyt., s. 25; M. B or ow i ej ska-Birken maje row a, Serce Polski. Zabytki i świadomość narodowa, Kraków 1991, s. 113. 
i świadomość narodową. Atmosferę ówczesnego Krakowa najlepiej wyrażają słowa nakreślone przez Stanisława Wyspiańskiego w Wyzwoleniu: „Tu wszystko jest Polska, kamień każdy i okruch każdy, a człowiek, który tu wstapi staje się Polski częścią, budowy tej częścią",

\section{Autonomous Cracow a Treasury of National Souvenirs Summary}

Cracow, the old capital of Polish Kingdom, has always performed a particular role in the Polish history and culture. In the period of galician autonomy 1860-1914, Cracow became the spiritual capital of Poland for generations of Poles who lived in the partitioned country, which was ruled by the three foreign powers together. About this phenomenon decided not only the autonomy but also the old tradition, suburban folklore and the symbolism of this town. In the 19 th century and before the First World War, Cracow was the most influential centre of the Polish national life.

${ }^{47}$ S. W y s p i a ń s k i, Dzieła zebrane, t. 5, Kraków 1959, s. 55. 